Open Access

\title{
Understanding the entrepreneurial intention among international students in Turkey
}

\author{
Berto Usman ${ }^{1 *}$ (D) and Yennita ${ }^{2}$
}

\author{
*Correspondence: berto_usman@ \\ unib.ac.id \\ ${ }^{1}$ Department of Management, \\ Faculty of Economics and Business, \\ University of Bengkulu, Jalan. WR \\ Supratman, Kandang Limun, \\ Bengkulu 38121, Indonesia \\ Full list of author information is \\ available at the end of the article
}

\begin{abstract}
This paper sets out to ascertain and to revisit the concept of Entrepreneurial Intention (El) among international students in Turkey. By utilizing Ajzen's theory of planned behavior (TPB) as the explaining model, this paper shows that El obviously exists among the international students in Turkey. In particular, the respondents were determined by using simple random sampling method. Hereby, self-administered online questionnaires were delivered to several social media platform groups, such as WhatsApp, e-mail, Messenger, and Facebook groups of international students who recently study in 12 big cities and 25 universities across Turkey. By employing correlation, descriptive statistics, and structural analysis, the results notify that Personal Attitude (PA) and Subjective Norm (SN) of international students in Turkey generally show high mean scores. Otherwise, the Perceived Behavioral Control (PBC) performs neither high nor low mean score. Furthermore, the structural test output by utilizing SmartPLS3 indicates that PA and PBC statistically perform significant and positive direct effect on El. Whilst, on the other hand, SN does not appear to statistically contribute to the variation of El.

Keywords: Entrepreneurial intention, Personal attitude, Subjective norm, Perceived behavioral control
\end{abstract}

\section{Background}

Entrepreneurial activity in the academic area is widely known as a way to broaden the competitive advantages of students, particularly in preparing them for the harsh competition in globalization era. Currently, the borderless space and communication lead students in universities to adopt the essence of entrepreneurship as one of the necessary skills. Take, for instance, Finland as reported by do Paço et al. (2011) has extensively included entrepreneurial subject into its curriculum. This program even looks similar to vocational training which is commonly found in the vocational school. Further, several developed countries such as Germany, Austria, and Switzerland have also begun significant efforts in establishing entrepreneurship education into their educational system (do Paço et al., 2011).

In today's world, the entrepreneurship education is assumed as enhancing factor in developing the existence of a country in its global positioning. The trait of entrepreneurship commonly associated with entrepreneurial success which provides skills as needed by students. Therefore, Rushing, (1990) has noted that the model of entrepreneurial education should be integrated and be continued throughout the formal education in every country.

(c) The Author(s). 2019 Open Access This article is distributed under the terms of the Creative Commons Attribution 4.0 International License (http://creativecommons.org/licenses/by/4.0/), which permits unrestricted use, distribution, and reproduction in any medium provided you give appropriate credit to the original author(s) and the source, provide a link to the Creative Commons license, and indicate if changes were made. 
It is also highlighted by the empirical study of Mueller et al., 2014a who document that prior entrepreneurial exposure is positively associated with the entrepreneurial intention of 253 students in German and Ethiopia. By meticulously considering entrepreneurship in the educational curriculum, it can help the government to develop better economic prospects and the potentials of entrepreneurial sector towards economic growth.

We consider that the investigation on entrepreneurial characteristics among students is important to be revealed. One triggering factor that can be considered as one of the key success factors in determining whether a business creation is well prepared or not, is relating to the entrepreneurial intention of the actors itself. For this reason, Ajzen's, theory (1985) has been extensively developed to discover the appropriate models in the area of entrepreneurial intention. As a result of this, some researchers have been passionately concerned with enhancing various models based on the primary theory planned of behavior (TPB) as documented by Ajzen, (1985). For instance, Krueger et al. (2000) note that individual's attitude towards behavior, perceived social norms, and individual's self-efficacy incline to influence the intention of individual itself. Moreover, Miller et al. (2009) and Usman (2016) confirm that the importance of intention in entrepreneurship is related to the personal attitude, subjective norm, and perceived behavioral control.

The idea of utilizing the concept of entrepreneurial intention toward the case of the international student is based on the study conducted by do Paço et al. (2011). Their model assumes that the entrepreneurial intention (EI) can be more effectively explained by employing the concept of Ajzen's theory (1985). In this case, the combination of Ajzen's theory will be considered to become effective predictors in explaining the phenomenon of entrepreneurial intention (EI) among the international students. Furthermore, previous study as documented by Sušanj et al. (2015) also argues that the strongest impact on the process of forming entrepreneurial intention comes from the evaluation of feasibility, entrepreneurial self-efficacy, desirability of entrepreneurship, and social norms perceived by the entrepreneur itself. Therefore, the dynamics of entrepreneurial intention is appropriate to be explained by the usage of Ajzen's TPB theory. As study developed by do Paço et al. (2011), the key aspects of TPB theory are consisting of personal attitude (PA), subjective norm (SN), and perceived behavioral control (PBC). Another study conducted by Zhang et al. (2015) reports that Ajzen's theory has been widely applied to study intention. Given that, the Ajzen's theory of TPB comprising of attitude, social norm, and controlled behavior is considerably conjectured to act as the predictors of intention towards certain action in future.

Our study contributes to the burgeoning number of academic literature concerning the concept of entrepreneurial intention in international studies. In particular, this study continues the discussion on the implementation of TPB model based on the perception and integrated results of short-term and long-term entrepreneurial intention preferences. More precisely, the contextual setting of this study is international university students. The expected theoretical contribution on the entrepreneurship literature using the theory of TPB is by presenting the full tests of TPB model in the entrepreneurship context. The contextual setting will also enable this study to appreciate the findings of entrepreneurial intention that is unique to international university students in Turkey. In this regards, even though TPB theory is criticised due to the unavailability of specific measure for the entrepreneur intention and its nature as the model of attitudes theory, prior study has documented that the perceived behavior control in the 
TPB model provides a relevant proxy for self-perception on the ability of individuals' to be involved and start the entrepreneurship initiatives (Haugh, 2005).

Considering the applicability and due to the appropriateness of TBP theory in the entrepreneurship research (Kautonen et al., 2015; Lortie \& Castogiovanni, 2015), we consider that utilizing TPB theory may encourage future research in this area. In this regard, the purpose of our study tries to advance the current literature by (1) providing a review and descriptive elaboration on the entrepreneurship literature, which adopts TPB theory in explaining the driving factors of entrepreneurship intention among students. (2) Synthesizing the related literatures and presenting empirical findings that investigate the variation of entrepreneurship intention by adopting the TPB model as suggested by Ajzen (1991).

The structure of this paper is designed as follows. First, it presents the theoretical background to support the content and elaboration regarding the variables employed. Second, it explains the sampling method, survey method, descriptive analysis about the demographical profile of respondents, the results of correlation analysis and structural analysis used in the study. Third, it exposes the results and develops discussions regarding the statistical outputs reported from the descriptive and structural analysis. Finally, it comprehensively concludes the findings along with the opportunity of developing the future research.

\section{Literature review and hypothesis development}

In the field of entrepreneurship, entrepreneurial intention as a social phenomenon has been well documented by many researchers (Carr \& Sequeira, 2007; Hisrich, Bucar, \& Oztark, 2003; Palmer et al., 2015; Patache \& Mitran, 2014). In particular, the entrepreneurial intention of an individual is recently understood as mainstream in the new business concepts. Moreover, there is huge evidence that virtually all of recent studies representing important model for the entrepreneurship works of literature. Thus, subsequent positive influences in employment creation are needed to be explored. Consequently, entrepreneurial intentions are closely associated to behavior, attitudes, subjective norms and perceived behavioral controls as noted by (Ajzen, 1985, 1991).

According to the Theory of Planned Behavior (TPB) as reported by Mueller et al. (2014a) three distinctive concepts of the antecedents incline to determine an individual's intention namely, (1) personal attitude towards the focal behavior, which reflects an individual's expectations about desirable, or undesirable consequences resulting from the focal behavior, (2) subjective norm that indicates the individual's perception of social pressure by attachment figures to carry out or refrain from the focal behavior, and (3) perceived behavioral control which represents individual's perceived capability to conduct the intended behavior. The relationship between these three distinctive constructs of traditional model of TPB as revealed by Ajzen's theory is displayed in Fig. 1 as follow.

As previously explained, a number of seminal studies have been conducted to identify and investigate the behavior of entrepreneurial intention among university students (e.g., Palmer, Griswold, Eidson, \& Wiewel, 2015; Patache \& Mitran, 2014). Students, particularly who resort to pursue business ideas in making decision towards implementing business idea are obviously related to their level of entrepreneurial intention. In this case, the process of realizing the idea toward the real implementation is not a simple activity, and even quite difficult. Further, Engel et al. (1995) report that this 


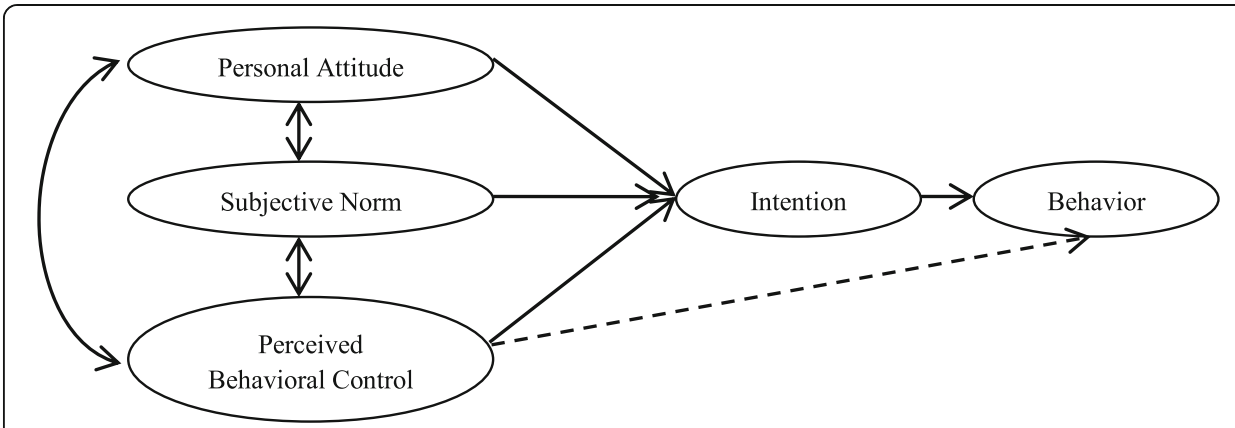

Fig. 1 Theory of planned behavior (TPB). Sources: Ajzen, (1985, 1991b); Zhang, Wang, \& Owen, (2015)

procedure includes the decision process which precedes the captured activities. Thus, it can be emphasized that the steps of being an entrepreneurship are a chain of process.

Inter-relation between personal attitude (PA), subjective norm (SN), perceived behavioral control (PBC), and entrepreneur intention (EI)

The review of recent works of literature is used to measure the role of TPB theory towards entrepreneurial intention, in which the results of prior literature suggest some possible generalizations. Several empirical evidences suggest positive links between entrepreneurship intention and decision-making process as a robust association. Moreover, Florin et al. (2007); Kamaludin and Usman (2016) point out that students generally need to perceive the application of soft skill. This skill will obviously be feasible where the entrepreneurial approach is desirable to build strong entrepreneurial intention as a focus on developing a positive attitude toward entrepreneurial behavior. Therefore, for most of the university students, it is important to note that entrepreneurship education is clearly needed to stimulate the success of entrepreneurial mindset that includes entrepreneurial intention and behavior. Additionally, the study of Mueller et al. (2014a) confirms that entrepreneurial exposure and entrepreneurial intention have shown a robust association for the students who study in German and Ethiopia.

As documented by Ajzen (1991), intention is determined as a fundamental requirement for the reasoned action. In this circumstance, Ryan (2016) points out that entrepreneurship encourages every opportunity identification behavior which creates intentionality as a key factor in explaining the role of thinking, particularly in terms of meeting the new venture formation. Moreover, the concept of entrepreneurial intentions is assumed as the single best predictor of planned behavior as suggested by Ajzen (1991). Hereby, Ryan (2016) also concerns on intention as the surrogating factor of motivation and conscious effort from individuals in determining a specific decision-making procedure. Therefore, Carr and Sequeira (2007) in their previous findings argue that entrepreneurial intention inclines to be connected to those actions which individuals take prior to the start-up of certain business creation.

Wilson et al. (2009) study the entrepreneurial intention and entrepreneurial self-efficacy by employing respondents from two different groups. First, the middle and high school students, and the second group comprises of the MBA students and early career adults. Their study reports that gender plays important role in explaining the relationship between entrepreneurial intention and self-efficacy. in their case, they point 
out that when someone or individual is considering the self-efficacy, the relationship between entrepreneurial intention and gender is declining. Given that, they report that entrepreneurial behavior and self-efficacy become significant, just in case if it is perceived by the early career adults. Furthermore, Buttar (2015) studies the role of sociocognitive factors in the exposition of entrepreneurial career intention. In his study, Buttar (2015) uses self-efficacy, subjective norm and perceived desirability in his nomological network. He specifically uses the TPB factors as the mediating variable between the relationship of social capital and entrepreneurial career intention. He reports that TPB factors can play the role as mediation factor between the relationship of social capital and entrepreneurial career intention among 636 Turkish and Pakistani undergraduate business students.

Molaei et al. (2015) show that the decision to start (entrepreneurial intention) a business preceded the opportunity recognition for certain entrepreneurs. The decision was influenced by the entrepreneurs' personal and environmental circumstances at the current time. They point out that the reasons are numerous and specific to the individuals at the time. However, they focus on what all had in common is that the decision to start a venture preceded the choice of a particular opportunity for a committed pursuit. Souitaris et al. (2007) and Noorkatina et al., 2015) consider intention as a condition where an individual incline to start several entrepreneurial activities. In respect of this, intention plays a specific role in order to support and develop entrepreneurship activities. Moreover, in this context, the entrepreneurial intention tends to perform direct relationship on the experiences and individual behavior. Given the underlying theory, prior studies, and the logic beyond the relationship between personal attitude, subjective norm, and the perceived behavioral control on entrepreneurial intention, thereby we formulate the hypothesis one to hypothesis six as follows.

Hypothesis 1. Personal attitude (PA) positively affects entrepreneur intention (EI).

Hypothesis 2. Perceived behavioral control (PBC) positively affects entrepreneurial intention (EI).

Hypothesis 3. Subjective norm (SN) positively affects entrepreneurial intention (EI).

Hypothesis 4. Subjective norm (SN) positively affects personal attitude (PA).

Hypothesis 5. Subjective norm (SN) positively affects perceived behavioral control (PBC).

Hypothesis 6. Personal attitude (PA) positively affects perceived behavioral control (PBC).

Figure 2 visually displays the model of bivariate and multivariate relationship among the employed variables. As noted in the traditional TPB model and prior studies, it is expected that the effects of SN to PA, SN to PBC and PA to PBC are considered to perform positive association.

\section{Research method}

This research is categorized as a descriptive quantitative study which concentrates on investigating the implementation of a theory and its implication towards a specific case in real concept. Our study is firstly started by identifying the sources of supporting data relating to entrepreneurial intention such as; finding the relevant supporting literature, developing research instruments, conducting online survey toward respondents, compiling the data, and finally interpreting the data by employing statistical tool analysis. 
Notes:

$\mathrm{H} 1:\left[\mathrm{PA} \rightarrow{ }^{+} \mathrm{EI}\right]$

$\mathrm{H} 2:\left[\mathrm{PBC} \rightarrow{ }^{+} \mathrm{EI}\right]$

$\mathrm{H} 3:\left[\mathrm{SN} \rightarrow{ }^{+} \mathrm{EI}\right]$

$\mathrm{H} 4:\left[\mathrm{SN} \rightarrow{ }^{+} \mathrm{PA}\right]$

$\mathrm{H} 5:\left[\mathrm{SN} \rightarrow{ }^{+} \mathrm{PBC}\right]$

$\mathrm{H} 6:\left[\mathrm{PA} \rightarrow{ }^{+} \mathrm{PBC}\right]$

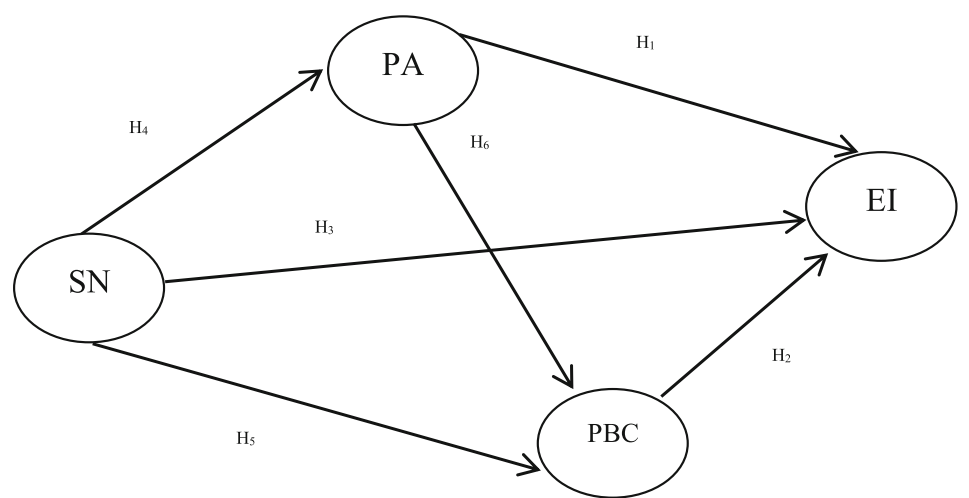

Fig. 2 The proposed research model of entrepreneurial intention

In this research, the instrumental modeling of entrepreneurial intention (EI) is developed as study conducted by do Paço et al. (2011). Necessary adjustments have been made on the questionnaire items to fit the research context. It is interesting to use the questionnaire as developed by do Paço et al. (2011) due to its applicability on the students self-perception measurement. In their study, they focus more on investigating the entrepreneurship intention of the students in two secondary student classes. To advance their study, we use different setting, in which we circulated the self-administrated survey to the international university students who study in Turkey. The survey instruments were subsequently translated into Turkish and English. Most of international students in Turkey are trilingual speakers, in which they speak English, Turkish and their native languages. Before circulating the questionnaire into two languages, the survey instruments were checked by a bilingual team member who are the native Turkish and English speakers to ensure that the item of questionnaires contain the same connotations in the two languages.

In terms of sampling procedures, this research employed the simple random sampling method in obtaining the specific and comprehensive respondents. A compilation of questionnaires was delivered through several social media platforms such as WhatsApp, e-mail, Messenger, and Facebook groups of international students in Turkey. Moreover, the data analysis utilized descriptive statistical analysis and structural analysis. Based on the final data, it is noted that totally there are 122 respondents participated. These respondents live in 12 big cities and study in 25 universities across Turkey. Virtually all of the respondents took part an active engagement in the process of data collection.

Regarding data analysis and its interpretation, we firstly employ descriptive statistics analysis on the mean scores of respondents' perception on the related latent variables. In this regards, we use five Likert-scales to empirically measure the proposed construtcs. To operationalize the latent variable, we adopt five questions for the variable of personal attitude (PA), three questions for the variable subjective norm (SN), five questions for perceived behavioral control (PBS) and six questions for variable entrepreneurial intention (EI) (See., Appendix for the detail items of questionnaire and its scale of measurements). Our analysis further continues to the correlation analysis, and each indicator used as the reflective indicators should have followed the procedures of validity and reliability test. After meticulously conducting the reliability and validity test, structural analysis and hypothesis testing are performed consecutively. Hereby is enclosed the specific 
information with respect to descriptive analysis of respondents' and structural analysis in the section of results and discussion.

\section{Results}

This section starts to elaborate on the data by displaying the general characteristics of respondents' demography. Thereby, demographical information regarding to respondents' nationality, gender, age, the source of educational funding, the city they study in, the degree of education, fields of study, university, and work experiences of respondents are provided. The specific information can be retrieved from Figs. 3, 4 and Table 1 as follow.

Most of the international students who study in Turkey come from various countries. As can be seen in Fig. 3, the respondents in this study are dominated by the students from Asia, Africa, and East European countries. Also, according to the obtained data, the number of Indonesian students participated in the online survey was $32 \%$ of the total respondents. The distribution of international students according to their university is available as follows.

\section{Reliability and validity analysis}

Further, besides the summary statistics relating to the demography of respondents, this study also examines the appropriateness and the precision of instrumental questions in the questionnaires delivered to the respondents. Given that, this research specifically employed reliability and validity test toward the indicators that are used to measure the specific latent variables comprising of Personal Attitude (PA), Subjective Norm (SN), Perceived Behavioral Control (PBC), and Entrepreneurial Intention (EI) of International students in Turkey. Validity test for each instrument was conducted by cross loading

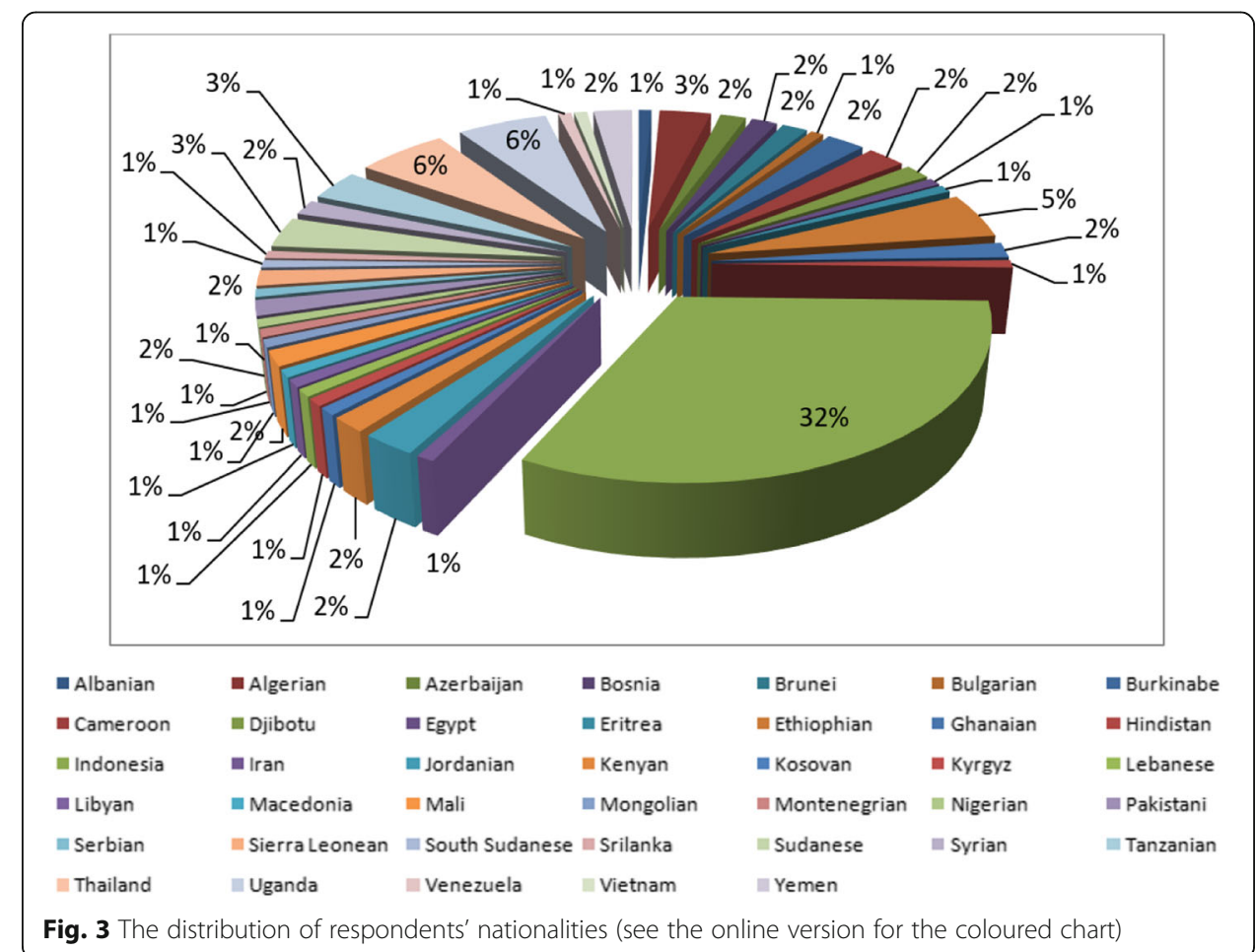




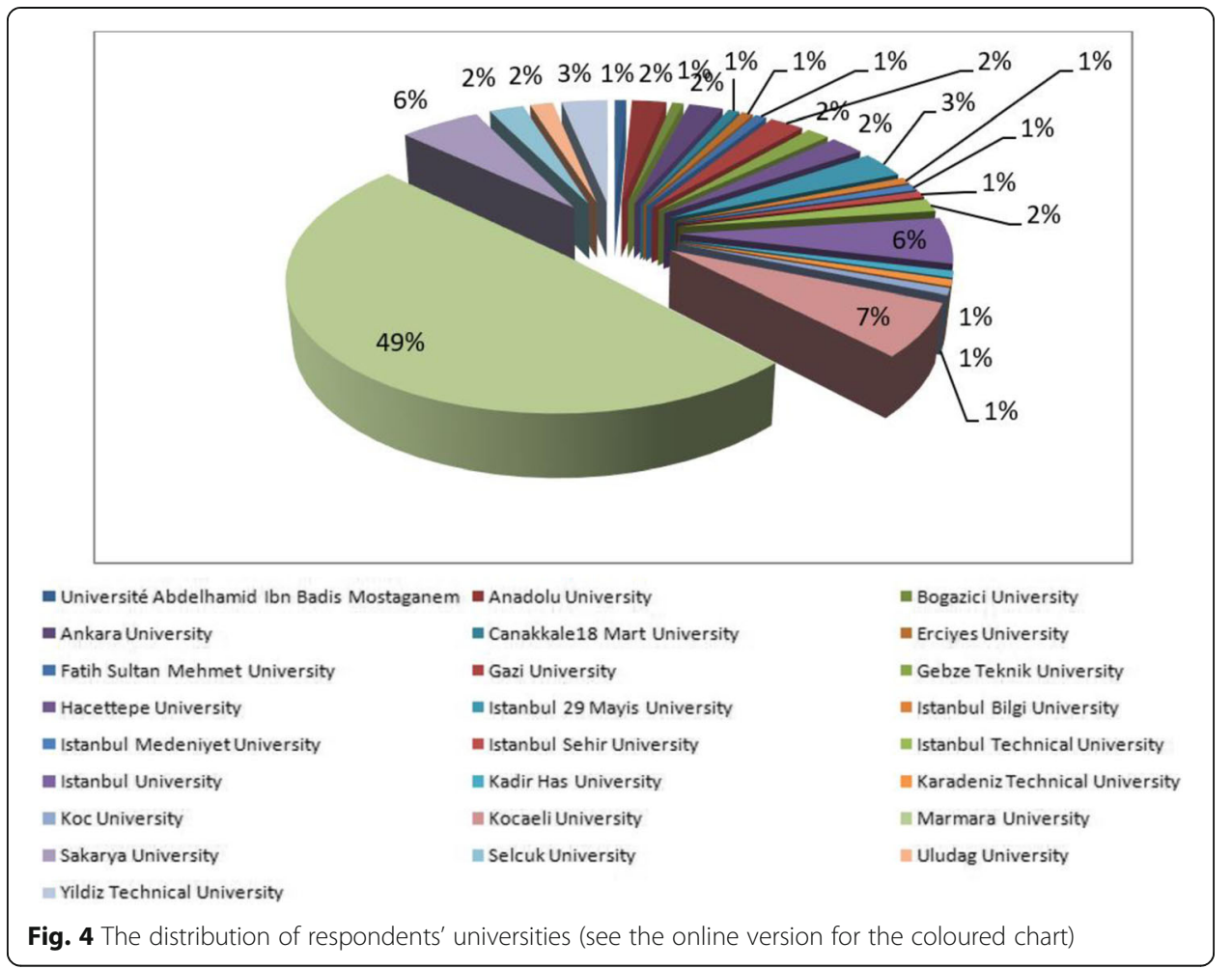

value, and the reliability test results were depicted by utilizing composite reliability and Cronbach alpha value as presented in Table 2 and Table 3 as follows.

The outputs shown in Tables 2 and 3 indicate that every indicator has met the validity test (the cross-loading of each indicator are relatively high, and the score of AVE value on each construct show value higher than 0.5.). The employed indicators also perform high reliability with the threshold level of Cronbach alpha greater than 0.60 on average (see., Hair, Black, Babin, \& Anderson, 2010). Likewise, the composite reliability shows outputs that range from 0.887 to 0.944 which is bigger than the threshold level 0.6. To make sure that the factors used in this study associated with the dynamics of entrepreneurial intention among international students in Turkey, this study also provides the result of latent variable correlation test by employing inter-correlation analysis towards each variable as can be observed in Table 4 .

Table 4 provides the specific information with respect to the correlation analysis between each variable employed in our study. As can be seen, there is a significant and positive correlation $(p$-value $<0.01)$ between PA (Personal Attitude) and SN (Subjective Norm) as 0.253 . However, this number shows a weak correlation. PA and PBC (Perceived Behavior Control) displays a bit relative strong correlation $(p$-value $<0.01)$, in which the value of correlation output between these variables is 0.561 . The strongest correlation $(p$-value $<0.01)$ is performed by PA and EI (Entrepreneurial Intention) as of 0.716. Furthermore, the correlation between $\mathrm{SN}$ and $\mathrm{PBC}$ is 0.232 , and the same tendency can also be found from the correlation between $\mathrm{SN}$ and $\mathrm{EI}$ as of 0.234 . This information indicates that the weak correlation exists between variable SN and PBC ( $p$-value $<0.05)$, in which variable SN and EI display the similar result $(p$-value $<0.05)$. The last correlation shown in Table 4 is between PBC and EI. The result reflects that these two variables show 
Table 1 Demographic profiles of respondents

\begin{tabular}{|c|c|c|c|}
\hline Variables & Demographical Information & Frequency $(n=122)$ & Percentage (\%) \\
\hline \multirow[t]{2}{*}{ Gender } & Female & 28 & 23.0 \\
\hline & Male & 94 & 77.0 \\
\hline \multirow[t]{5}{*}{ Age } & $<22$ Years Old & 36 & 29.5 \\
\hline & $23-25$ Years Old & 36 & 29.5 \\
\hline & 26-30 Years Old & 34 & 27.9 \\
\hline & 30-34 Years Old & 15 & 12.3 \\
\hline & $>35$ Years Old & 1 & 0.8 \\
\hline \multirow[t]{5}{*}{ Scholarship } & YTB Scholarships & 109 & 89.3 \\
\hline & TÜBITAK & 2 & 1.6 \\
\hline & IDB Scholarships & 1 & 0.8 \\
\hline & Vakifleri (Foundation) & 5 & 4.1 \\
\hline & Self-Funding & 5 & 4.1 \\
\hline \multirow[t]{12}{*}{ City } & Ankara & 7 & 5.7 \\
\hline & Bursa & 2 & 1.6 \\
\hline & Çanakkale & 1 & 0.8 \\
\hline & Eşkisehir & 3 & 2.5 \\
\hline & Isparta & 1 & 0.8 \\
\hline & Istanbul & 82 & 67.2 \\
\hline & Izmir & 1 & 0.8 \\
\hline & Kayseri & 3 & 2.5 \\
\hline & Kocaeli & 9 & 7.4 \\
\hline & Konya & 3 & 2.5 \\
\hline & Sakarya & 8 & 6.6 \\
\hline & Trabzon & 2 & 1.6 \\
\hline \multirow[t]{3}{*}{ Education } & Bachelor & 39 & 32.0 \\
\hline & Master & 45 & 36.9 \\
\hline & Doctoral & 38 & 31.1 \\
\hline \multirow[t]{5}{*}{ Field of Studies } & Sciences & 15 & 12.3 \\
\hline & Art and Humanities & 39 & 32.0 \\
\hline & Engineering & 12 & 9.8 \\
\hline & Social and Administrative Science & 53 & 43.4 \\
\hline & Agriculture & 3 & 2.5 \\
\hline \multirow[t]{5}{*}{ Work Experience } & Have no experience & 53 & 43.4 \\
\hline & 1-2 Years & 33 & 27.0 \\
\hline & 2-3 Years & 11 & 9.0 \\
\hline & $3-5$ Years & 9 & 7.4 \\
\hline & More than 5 Years & 16 & 13.1 \\
\hline
\end{tabular}

Sources: Own elaboration, 2018

relatively strong correlation ( $p$-value $<0.01)$ as 0.666 . Moreover, the next analysis by employing descriptive statistics analysis is performed as follows.

Table 5 indicates the results of descriptive statistics regarding international students' perspectives about personal attitude (PA). Hereby, respondents generally show high personal attitude, in which the mean score of personal attitude of international students who study in Turkey is 3.83 on average. Also, this result reveals that if the respondents have 
Table 2 Cross loading

\begin{tabular}{lllll}
\hline Indicator & El & PA & PBC & SN \\
\hline ei1 & $\mathbf{0 . 7 4 2}$ & 0.562 & 0.702 & 0.081 \\
ei2 & $\mathbf{0 . 8 9 5}$ & 0.638 & 0.546 & 0.233 \\
ei3 & $\mathbf{0 . 9 0 2}$ & 0.597 & 0.624 & 0.225 \\
ei4 & $\mathbf{0 . 8 9 7}$ & 0.616 & 0.512 & 0.203 \\
ei5 & $\mathbf{0 . 9 1 1}$ & 0.644 & 0.593 & 0.235 \\
ei6 & $\mathbf{0 . 8 0 1}$ & 0.633 & 0.434 & 0.232 \\
pa1 & 0.390 & $\mathbf{0 . 6 6 9}$ & 0.395 & 0.323 \\
pa2 & 0.617 & $\mathbf{0 . 8 6 4}$ & 0.524 & 0.224 \\
pa3 & 0.538 & $\mathbf{0 . 7 7 8}$ & 0.361 & 0.235 \\
pa4 & 0.594 & $\mathbf{0 . 8 6 7}$ & 0.470 & 0.198 \\
pa5 & 0.666 & $\mathbf{0 . 7 6 9}$ & 0.456 & 0.058 \\
pbc1 & 0.485 & $\mathbf{0 . 6 9 4}$ & 0.229 \\
pbc2 & 0.390 & 0.504 & $\mathbf{0 . 7 8 3}$ & 0.221 \\
pbc3 & 0.639 & 0.438 & $\mathbf{0 . 8 7 7}$ & 0.186 \\
pbc4 & 0.560 & 0.356 & $\mathbf{0 . 7 9 8}$ & 0.215 \\
pbc5 & 0.530 & 0.468 & $\mathbf{0 . 8 7 2}$ & 0.087 \\
sn1 & 0.534 & 0.159 & 0.182 & $\mathbf{0 . 7 6 5}$ \\
sn2 & 0.106 & 0.182 & 0.119 & $\mathbf{0 . 8 7 4}$ \\
sn3 & 0.143 & 0.271 & 0.255 & $\mathbf{0 . 9 0 9}$ \\
\hline sources: & 0.286 & & &
\end{tabular}

Sources: Own elaboration, 2018

the opportunity and enough resources, they would like to start their own business. The willingness of respondents to start the business creation regarding their attitude is documented as the highest mean score (4.13) among five instruments provided in Table 5. In this context, the relationship between personal attitude and entrepreneurial intention has not been sufficiently taken into account. Due to this reason, it is interesting to address this gap. It is speculated that a high personal attitude is likely well connected to intention in starting a new business creation. Nevertheless, in the logic sense, personal attitude and entrepreneurial intention positively interact. Indeed, individuals who passionately perform positive attitude are confident and highly motivated to start their business creation. Furthermore, the elaboration to the subjective norm is available in Table 6 as follows.

According to the result of international students' perceptions, it can be observed that the overall mean score for the variable of subjective norm $(\mathrm{SN})$ is 3.65 . This number reveals that the subjective norm in terms of respondent's environment is relatively high. Based on the mean scores of instruments, the supports to start a new business is clearly more influenced by friends (3.76) rather than close family (3.68) and colleagues (3.52). In this case, individuals who perceive a high level of support from their subjective environment generally show higher level of confidence. By having some supports about their skills and abilities, individuals will show higher willingness (entrepreneurial intention) to create a new economic activity. The next elaboration regarding perceived behavioral control is given as follows.

The overall mean score of respondents relating to the variable of perceived behavioral control (PBC) is 2.96. This value is in the category of neither high nor low. Given that, the respondents have general assumption that they actually do not clearly have strong 
Table 3 Reliability and validity analysis

\begin{tabular}{lllll}
\hline Construct & AVE $^{\mathrm{a}}$ & Composite Reliability $^{\mathrm{b}}$ & $\mathrm{R}^{2}$ & Cronbach Alpha $^{\mathrm{b}}$ \\
\hline EI & 0.740 & 0.944 & 0.616 & 0.928 \\
PA & 0.628 & 0.893 & 0.064 & 0.850 \\
PBC & 0.652 & 0.903 & 0.323 & 0.865 \\
SN & 0.725 & 0.887 & - & 0.819 \\
\hline
\end{tabular}

Sources: Own elaboration, 2017

aalid if AVE value $>0.5$

${ }^{\mathrm{b}}$ Reliable if Composite Reliability or Cronbach's alpha $>0.6$

confidence to start their own business. This circumstance is triggered by their belief that formal education is still considered as the most important path for the students. Therefore, even though the respondents fundamentally know about the rudiments and the essence of entrepreneurship, but most of the respondents give the best priorities to education instead of focus on starting a business. Perceived behavioral control is also argued to be an important predictor of the entrepreneurial intention. As pointed out by Boukamcha (2014) the project feasibility perception can be relied on to predict the probability of entrepreneurial intention. In this regard, Boukamcha (2014) conjectures that individuals are more likely to develop an intention to create their own start-up businesses. It can only happen if they have favorable attitudes toward entrepreneurship.

Table 7 shows the mean score of entrepreneurial intention among international students in Turkey. Based on the overall mean score, the result pertaining to the readiness of respondents to start their business is relatively high, in which the mean score of entrepreneurial intention (EI) is around 3.22 on average. Also, even though not all respondents have strong willingness to start their own business, but generally they give the highest score to the fourth instrument. Otherwise, for the current time, most of the respondents are not ready to start their own business yet. It is proven by the lowest mean score as indicated by the first instrument (3.02). It denotes that after completing their focus major in education, they tend to consider entrepreneurship as the activity that can boost their future life.

The results in this study are also aligned with previous research showing that respondents or individuals who previously have received university-level classes in entrepreneurship basically have greater intentions to start a new business. However, in terms of the process of their study, most of the respondents are not showing a huge passion to

Table 4 Summary of inter-latent variable correlation analysis

\begin{tabular}{llll}
\hline Variables & PA & SN & PBC \\
\hline SN & $0.253^{\mathrm{b}}$ & & \\
& 0.007 & & \\
PBC & $0.561^{\mathrm{b}}$ & $0.232^{\mathrm{a}}$ & \\
& 0.000 & 0.017 & $0.666^{\mathrm{b}}$ \\
EI & $0.716^{\mathrm{b}}$ & $0.234^{\mathrm{a}}$ & 0.000 \\
& 0.000 & 0.021 & \\
\hline
\end{tabular}

Sources: Own elaboration, 2018

${ }^{a}$ Correlation is significant at the 0.01 level (2-tailed)

${ }^{\mathrm{b}}$ Correlation is significant at the 0.05 level (2-tailed) 
Table 5 Summary statistic of students' perspectives about personal attitude (PA)

\begin{tabular}{|c|c|c|c|c|c|c|c|c|}
\hline \multirow[t]{2}{*}{ No } & \multirow[t]{2}{*}{ Instruments } & \multicolumn{5}{|c|}{ Answer scores } & \multirow[t]{2}{*}{ Scores } & \multirow[t]{2}{*}{ Mean } \\
\hline & & $\overline{V L}$ & $\mathrm{~L}$ & NHNL & $\mathrm{H}$ & $\mathrm{VH}$ & & \\
\hline pa1 & $\begin{array}{l}\text { Being an entrepreneur implies more advantages } \\
\text { than disadvantages to me }\end{array}$ & 4 & 4 & 27 & 53 & 34 & 475 & 3.89 \\
\hline pa2 & A career as entrepreneur is attractive for me & 2 & 6 & 27 & 55 & 32 & 475 & 3.89 \\
\hline pa3 & If I had the opportunity and resources, I'd like to start a firm & 4 & 6 & 13 & 46 & 53 & 504 & 4.13 \\
\hline pa4 & Being an entrepreneur would entail great satisfactions for me & 2 & 8 & 29 & 52 & 31 & 468 & 3.83 \\
\hline pa5 & Among various options, I would rather be an entrepreneur & 3 & 18 & 47 & 34 & 20 & 416 & 3.40 \\
\hline \multicolumn{2}{|c|}{ Total Score } & & & & & & 2338 & 19.16 \\
\hline \multicolumn{2}{|c|}{ Mean } & & & & & & & 3.83 \\
\hline
\end{tabular}

Sources: Own elaboration, 2018

"Very low (VL)" with mean score ranges between 1.00 and 1.80, "Low (L)" (1.81-2.60), "Neither high nor low (NHNL)" (2.61-3.40), "High $(\mathrm{H})$ " (3.41-4.20), and "Very high $(\mathrm{VH})$ " (4.21-5.00)

start a new business. This information confirms the study reported by Sušanj et al. (2015) who documented that those who get better knowledge in university level, they will gain a better understanding than those who have no knowledge about entrepreneurship. But in a specific case, most of the students have strong tendency to be focused on finishing their study before continuing to start a new business. Moreover, Boukamcha (2014) notices that individual with a high level of desirability in business may feel enthusiastic about the process of creation of a new business. Hereby, Boukamcha (2014) suggests that desirability is related to personal values and career choices. In line with the previous studies, this paper implies that individuals who experience a high personal attitude (PA), subjective norm (SN), and perceived behavior control (PBC) tend to develop a high entrepreneurial intention (EI).

According to the findings, it is clear that international students who are exposed to entrepreneurship education either formally or informally have huge potentials to become entrepreneurs in the future. This finding is relevant to the study conducted by Noorkatina et al. (2015) who reveal that university students have strong willingness to start their business in nature. However, due to the lack earlier focus toward entrepreneurial activity, most all of university students performed the negative relationships. It denotes that most of the students have passionately focused on finishing their formal education besides starting to build a business creation. This finding shows that in the current time, students put education as the priority

Table 6 Summary statistic of students' perspective about subjective norm (SN)

\begin{tabular}{|c|c|c|c|c|c|c|c|c|}
\hline \multirow[t]{2}{*}{ No } & \multirow[t]{2}{*}{ Instruments } & \multicolumn{5}{|c|}{ Answer scores } & \multirow[t]{2}{*}{ Scores } & \multirow[t]{2}{*}{ Mean } \\
\hline & & $\overline{V L}$ & $L$ & NHNL & $\mathrm{H}$ & $\overline{\mathrm{VH}}$ & & \\
\hline sn1 & $\begin{array}{l}\text { If you decided to create a firm, would your close family } \\
\text { in your environment approve of that decision? }\end{array}$ & 5 & 14 & 25 & 34 & 28 & 449 & 3.68 \\
\hline sn2 & $\begin{array}{l}\text { If you decided to create a firm, would your friends in } \\
\text { your close environment approve of that decision? }\end{array}$ & 4 & 7 & 30 & 40 & 25 & 459 & 3.76 \\
\hline sn3 & $\begin{array}{l}\text { If you decided to create a firm, would your colleagues } \\
\text { in your close environment approve of that decision? }\end{array}$ & 5 & 10 & 35 & 39 & 17 & 429 & 3.52 \\
\hline \multicolumn{2}{|c|}{ Total Score } & & & & & & 1337 & 10.96 \\
\hline \multicolumn{2}{|c|}{ Mean } & & & & & & & 3.65 \\
\hline
\end{tabular}

Sources: Own elaboration, 2018

"Very low (VL)" with mean score ranges between 1.00 and 1.80, "Low (L)" (1.81-2.60), "Neither high nor low (NHNL)" (2.61-3.40), "High $(\mathrm{H})$ " (3.41-4.20), and "Very high $(\mathrm{VH})$ " (4.21-5.00) 
Table 7 Summary statistic of students' perspective about entrepreneurial intention (EI)

\begin{tabular}{|c|c|c|c|c|c|c|c|c|}
\hline \multirow[t]{2}{*}{ No } & \multirow[t]{2}{*}{ Instruments } & \multicolumn{5}{|c|}{ Answer scores } & \multirow[t]{2}{*}{ Scores } & \multirow[t]{2}{*}{ Mean } \\
\hline & & $\mathrm{VL}$ & $\mathrm{L}$ & NHNL & $\mathrm{H}$ & $\mathrm{VH}$ & & \\
\hline ei1 & I am ready to do anything to be an entrepreneur & 11 & 20 & 32 & 26 & 11 & 371 & 3.04 \\
\hline ei2 & My professional goal is to become an entrepreneur & 16 & 14 & 29 & 23 & 18 & 373 & 3.06 \\
\hline ei3 & I will make every effort to start and run my firm & 6 & 15 & 30 & 32 & 17 & 407 & 3.34 \\
\hline ei4 & I am determined to create a firm in the future & 6 & 11 & 25 & 31 & 27 & 434 & 3.56 \\
\hline ei5 & I have very seriously thought of starting a firm & 12 & 12 & 22 & 31 & 23 & 410 & 3.36 \\
\hline ei6 & I have the firm intention to start a firm someday & 11 & 9 & 17 & 33 & 30 & 433 & 3.55 \\
\hline \multicolumn{2}{|c|}{ Total Score } & & & & & & 2428 & 19.90 \\
\hline \multicolumn{2}{|c|}{ Mean } & & & & & & & 3.22 \\
\hline
\end{tabular}

Sources: Own elaboration, 2018

"Very low (VL)" with mean score ranges between 1.00 and 1.80, "Low (L)" (1.81-2.60), "Neither high nor low (NHNL)" (2.61-3.40), "High (H)" (3.41-4.20), and "Very high (VH)" (4.21-5.00)

before deciding to run their prospective business. This circumstance even seems to the finding in this paper, in which international students in Turkey incline to be focus to start their business after completing their formal education in university.

There is still much more to be learned to fully understand the process that leads to the decision to become an entrepreneur. Nevertheless, the results presented in our paper provide some understanding of the factors influencing the entrepreneurial intention among international university students in Turkey. Thus, the results are exploratory and subject to validation by future studies using more representative samples. Nonetheless, this study has made a modest contribution to the effort in developing the concept of entrepreneurial intention among international university students in Turkey. To comprehensively understand the entrepreneurial intention (EI) among international students in Turkey, we further continue our analysis to structural analysis by utilizing SmartPLS3 for the next procedure of hypothesis testing.

\section{Structural analysis}

We do recognize that the latent variables used in the proposed model of Ajzen TPB theory cannot be measured directly. Given that, the analysis with structural equation modeling is considered to be adequate. We specifically employ SmartPLS3 as the statistical tool analysis in identifying the unknown parameters (e.g., factor loadings, error terms, path weights, and shared variance) in our structural equation modeling. As the result of this, the software normally calculates the data based on the statistical properties of the data provided, and then relating the real correlations or covariances to the hypothesized correlation or covariances as proposed in the structural research model (Gefen, 2000; Mertens, Pugliese, \& Recker, 2016). Following the procedure of structural equation analysis as performed by do Paço et al. (2011) we first compute the latent variables through an iterative procedures. These procedures require the regression regarding the outer and inner models, where the parameters of the one part of the model itself is necessarily being fixed while estimating those of the other part (Henseler \& Chin, 2010; Sarstedt, Henseler, \& Ringle, 2011). Further, the following step should be done by implementing 
the OLS with non-iterative regression, in which the outer and inner models are estimated with this procedure. In this regards, Chin, 1998contends that the quality of the developed model is determined by the value of coefficient of determination $\left(\mathrm{R}^{2}\right)$, or by applying the Jacknife and Bootstrap techniques.

As presented in Fig. 5, the model measurement in this study utilizes 19 indicators that are employed to measure four major constructs. In the proposed model above, all the indicators are the reflective indicators in nature. In this respect, each of indicator is supposed to measure the same construct. Furthermore, we also employ the bootstrapping technique. The purpose of doing the bootstrapping test is meant to test the weights' significance of each construct. Hereby, systematic deletion of observation is conducted to generate a large number of sub-samples which must be obtained from the original sample. In our test, as many as 500 valid sub-samples were extracted from the original samples. Eventually, by having 500 valid sub-sample, we were able to produce the average weights (see. Table 8).

Bootstrapping path results as shown in Fig. 6 provide several key information regarding the t-statistic value of each path and its indicators. It is clearly known that the threshold level of $t$-statistic value is significant if it is bigger than 2. Hereby, our results document that t-statistic of each reflective indicator is greater than 2 . However, the output in Fig. 6 also notes that path $\mathrm{SN} \rightarrow \mathrm{EI}$ and $\mathrm{SN} \rightarrow \mathrm{PBC}$ do not generate t-statistics which are greater than 2. Even though the path of $\mathrm{SN} \rightarrow \mathrm{EI}$

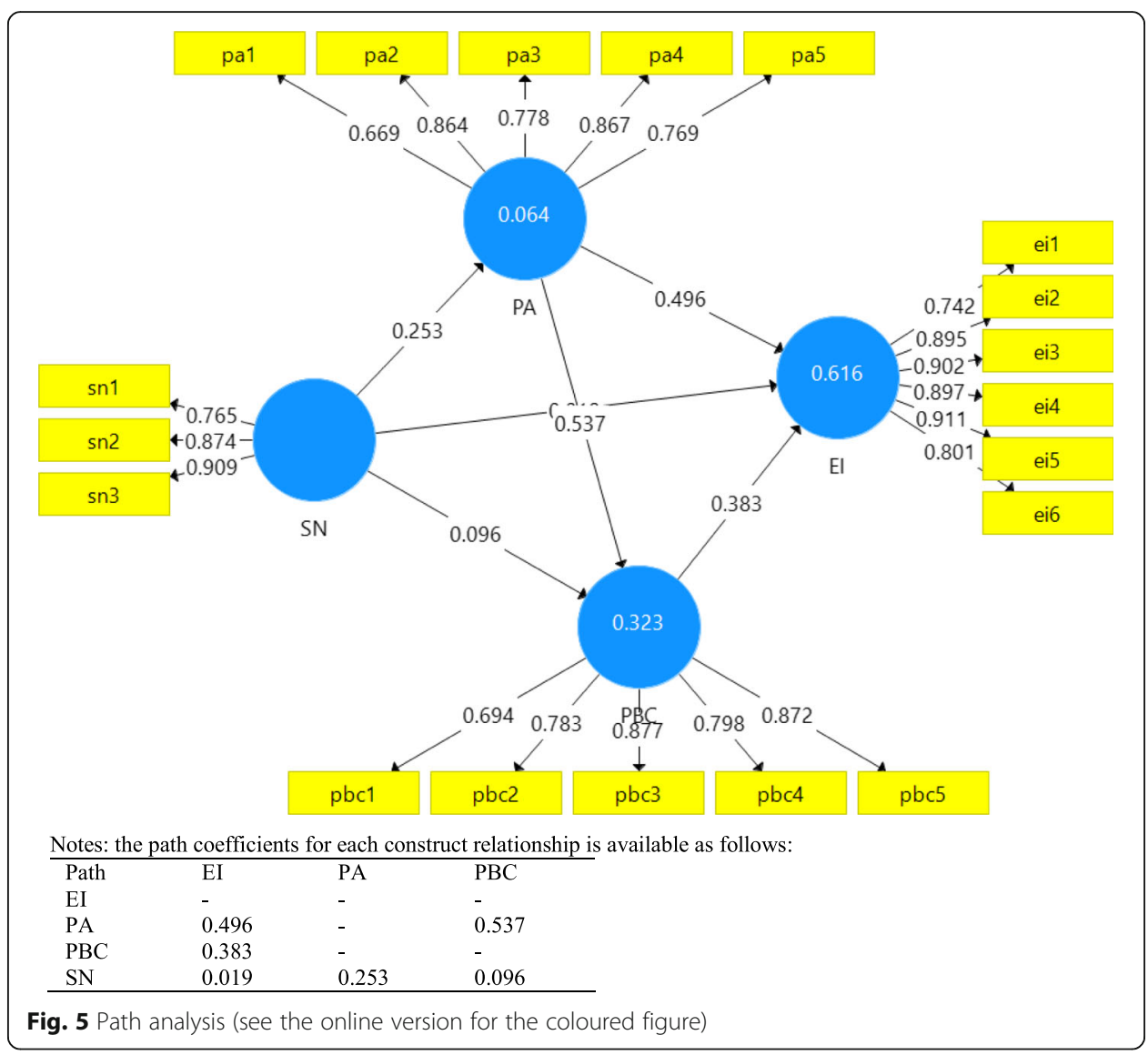


Table 8 Bootstrapping coefficient path output

\begin{tabular}{lllllll}
\hline Path & Expected sign & Original Sample & Sample Mean & Standard Deviation & t-statistics & $p$-values \\
\hline $\mathrm{PA} \rightarrow \mathrm{El}$ & + & 0.496 & 0.497 & 0.068 & 7.321 & 0.000 \\
$\mathrm{PBC} \rightarrow \mathrm{El}$ & + & 0.383 & 0.384 & 0.067 & 5.682 & 0.000 \\
$\mathrm{SN} \rightarrow \mathrm{EI}$ & + & $\mathbf{0 . 0 1 9}$ & $\mathbf{0 . 0 2 2}$ & $\mathbf{0 . 0 5 9}$ & $\mathbf{0 . 3 2 5}$ & $\mathbf{0 . 7 4 5}$ \\
$\mathrm{SN} \rightarrow \mathrm{PA}$ & + & 0.253 & 0.266 & 0.101 & 2.518 & 0.012 \\
$\mathrm{SN} \rightarrow \mathrm{PBC}$ & + & $\mathbf{0 . 0 9 6}$ & $\mathbf{0 . 0 9 6}$ & $\mathbf{0 . 0 7 1}$ & $\mathbf{1 . 3 6 3}$ & $\mathbf{0 . 1 7 3}$ \\
$\mathrm{PA} \rightarrow \mathrm{PBC}$ & + & 0.537 & 0.543 & 0.066 & 8.186 & 0.000 \\
\hline
\end{tabular}

500 Bootstrap subsamples

Sources: Own elaboration, 2018

and $\mathrm{SN} \rightarrow \mathrm{PBC}$ are statistically insignificant, but these two paths indicate that hypothesis three and five as the a priori notion of the hypothesis development are partially supported. The complete information concerning the bootstrapping coefficient and output is available in Table 8 .

Information in Table 8 obviously documents the output of bootstrap technique as obtained by generating a large sample of sub-samples from the original sample. It can be observed that there are two paths that are statistically insignificant ( $p$-value $<0.05$ ). The first path is $\mathrm{SN} \rightarrow \mathrm{EI}$ (Subjective Norm to Entrepreneurial Intention) and the second path is $\mathrm{SN} \rightarrow \mathrm{PBC}$ (Subjective Norm to Perceived Behavioral Control). Meanwhile, the other paths show that path one (PA $\rightarrow E I)$, two $(\mathrm{PBC} \rightarrow \mathrm{EI})$, four $(\mathrm{SN} \rightarrow \mathrm{PA})$ and six $(\mathrm{PA} \rightarrow \mathrm{PBC})$ are positively and statistically significant. Referring to the expected sign and the $p$-value of each path, our results indicate that four out of six hypotheses are supported. Moreover, the direct and indirect effect is analyzed by calculating the total effect of each path. The information of direct, indirect and total effects is available as follows.

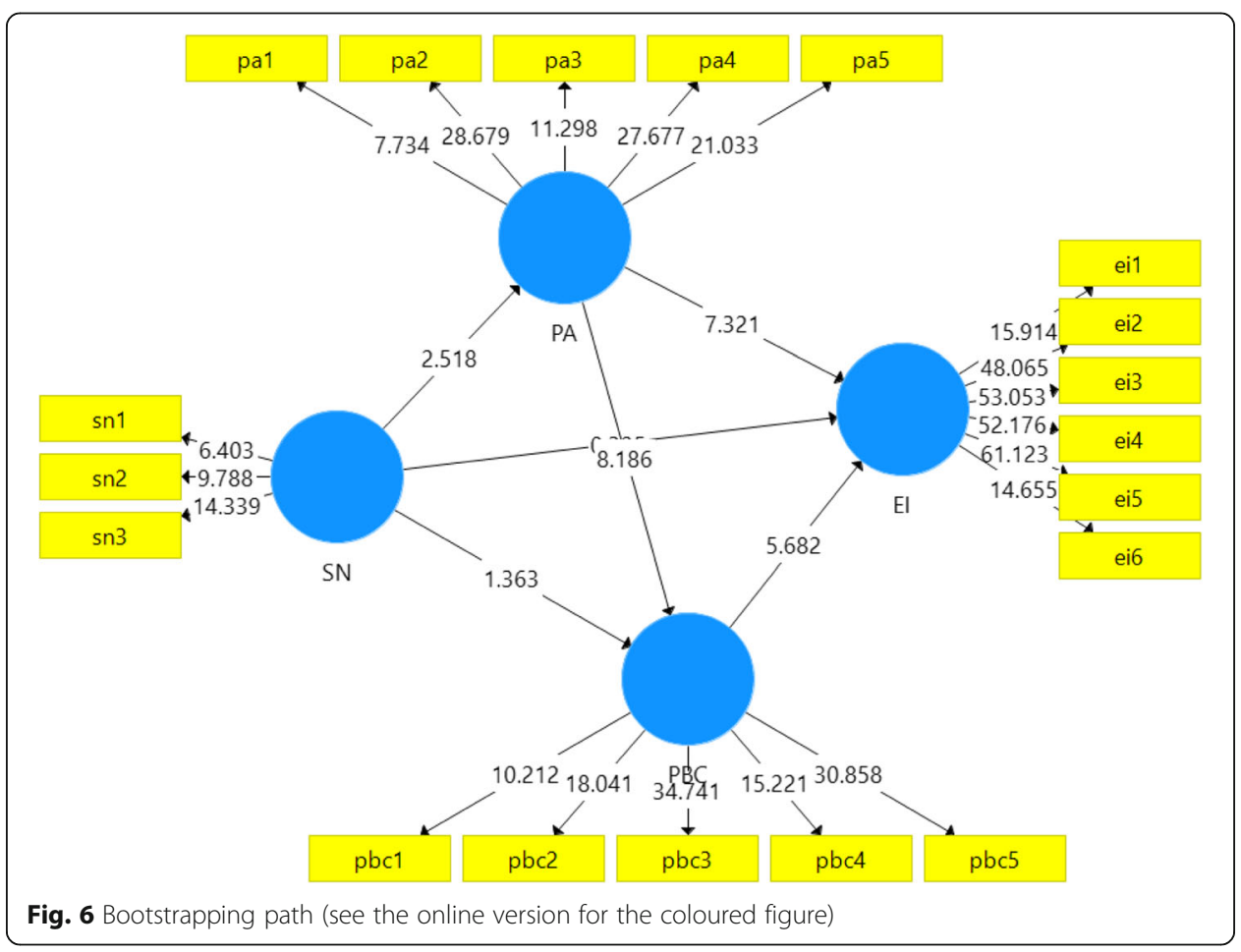


Table 9 presents the main information concerning the structural equation model of each path. Recall back to the literature review section, we conjecture that the TPB model is able to explain the propensity of variance in the entrepreneurial intention among international students in Turkey. Therefore, after meticulously testing the structural analysis, our results lead to the empirical hypothesis testing results. As noted in Tables 8 and 9, we have shown several information concerning the hypothesis testing with six path analyses. Hypotheses one, two, four, and six are statistically supported. While, on the other hand, hypothesis three and hypothesis five are partially supported.

\section{Discussion}

As provided in Table 9, the specific information with respect to the causal relationship (direct and indirect effects) between independent variables and dependent variables are reported. Recall that there are three main factors which are considered as the predictor of EI as noted by Ajzen (1991). Hereby, the measure is limited to the EI, and the respondent's behavior is not measured due to the focus of this study concerns on investigating the intention of respondents. Therefore, the causality test is done by solely examining the influences of variable PA (personal attitude), SN (subjective norm) and PBC (perceived behavioral control) on EI (entrepreneurial intention).

Referring to the statistical result in Table 9 and the final model in Fig. 7, it is discernibly observable that the expected signs of three predictors on EI are supposed to be positive. This expectation is fulfilled, in which the sign of each predictor shows positive coefficient value. Moreover, in order to know whether this output performs significant effect or not is identified through the observation on $p$-value or by comparing the critical values resulting from t-test with the t-table. Among the three main direct paths of independent variables, two variables are documented to display positive and significant direct effect on the variation of EI. PA positively and significantly $(p$-value $<0.01)$ contribute to the increase of EI with the direct effect as 0.496 and indirect effect 0.206 . This is followed by variable $\mathrm{PBC}$ which is positively and significantly $(p$-value $<0.01)$ contributing to the variation of EI with the direct effect as 0.383 . While, SN has performed positive value in terms of its effect sign but statistically insignificantly ( $p$-value $>0.05)$ to the variation of EI (see., Fig. 5 for more detail information).

To comprehensively understand the final model, we also do the exclusion on the insignificant path as documented in Table 9. Therefore, we rerun the second structural

Table 9 Effects

\begin{tabular}{llllll}
\hline Hypothesis & Path & Direct effect & Indirect effect & Total effect & Results \\
\hline Hypothesis 1 & $\mathrm{PA} \rightarrow \mathrm{El}$ & 0.496 & 0.206 & 0.702 & Supported \\
Hypothesis 2 & $\mathrm{PBC} \rightarrow \mathrm{El}$ & 0.383 & - & 0.383 & Supported \\
Hypothesis $\mathbf{3}$ & $\mathrm{SN} \rightarrow \mathrm{EI}$ & $\mathbf{0 . 0 1 9}$ (ns) & $\mathbf{0 . 2 1 5}$ & $\mathbf{0 . 2 3 4}$ & Partially supported \\
Hypothesis 4 & $\mathrm{SN} \rightarrow \mathrm{PA}$ & 0.253 & - & 0.253 & Supported \\
Hypothesis 5 & $\mathrm{SN} \rightarrow \mathrm{PBC}$ & $\mathbf{0 . 0 9 6}$ (ns) & $\mathbf{0 . 1 3 6}$ & $\mathbf{0 . 2 3 2}$ & Partially supported \\
Hypothesis 6 & $\mathrm{PA} \rightarrow \mathrm{PBC}$ & 0.537 & - & 0.537 & Supported \\
\hline
\end{tabular}

Sources: Own elaboration, 2018

ns $=$ non-significant with a 0.05 


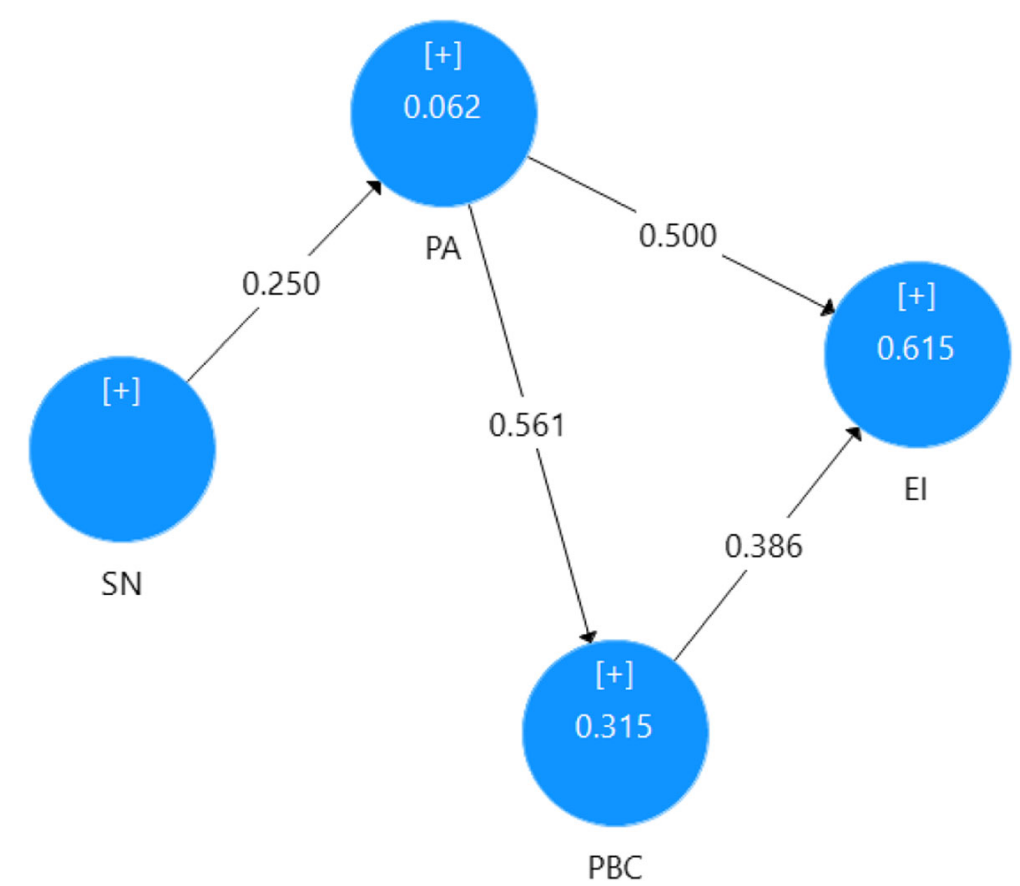

Fig. 7 Final structural model (see the online version for the coloured figure)

analysis by excluding path $\mathrm{SN} \rightarrow \mathrm{EI}$ and $\mathrm{SN} \rightarrow \mathrm{PBC}$ (see., Fig. 7). Our result as displayed in Fig. 7 shows hold evidence where the direct and indirect effect endogenous variable are similar compared to the previous structural analysis output when the two excluded paths are still in the model. The final model informs that the total effect of PA to EI is $(0.250+0.5000=0.750)$, while the total effect of PBC to EI is 0.386 . It denotes that variable PA and PBC relatively indicate stronger effect than SN to EI. Moreover, the new $\mathrm{R}^{2}$ as obtained from the second structural analysis in the Final model results in similar output with the first structural analysis. Hereby, the endogenous constructs in the final model indicate $\mathrm{R}^{2}$ values as 0.615 for EI, followed by PBC as 0.315 and PA (0.062) respectively.

Finally, our study suggests and indicates a consistent result as study conducted by do Paço et al. (2011). Even though we have conducted the study in different setting, the findings suggest a quite hold result. Our study also advances the prior study by discussing and providing empirical evidence in multicultural groups of observations (international students). The obtained results allow the readers to infer that multicultural group of samples is important to show the variability of entrepreneurial intention since the self-perception proxy has a propensity to depict the respondents' cross-culture exposure during their previous education and their stay in Turkey. Again, recall back to the purpose and the contribution of study, we eventually provides an empirical adoption of TPB theory in more general and multicultural group of respondents which was reported as one if the suggested issue in the prior studies. As recommendation to the next studies, we would like to suggest the researcher in the entrepreneurship area to consider and explore more on the interrelation between intention and planning. The usage of 
longitudinal data is also important to understand better the full TPB in entrepreneurship context.

\section{Conclusion remarks}

As has been already mentioned, this paper tries to understand the entrepreneurial intention among international students in Turkey. Another important objective is to explore the tendency of personal attitude (PA), subjective norm (SN), perceived behavioral control $(\mathrm{PBC})$ and entrepreneurial intention (EI) in the case of university students. According to the existing literature and data, entrepreneurial intention appears as a fundamental factor in determining whether the willingness of being entrepreneurs exist among the international students in Turkey. Therefore, there are some conclusions that are important to be inferred from the results of descriptive statistics.

Referring to the results of descriptive statistics analysis, Personal Attitude (PA) and Subjective Norm (SN) of international students studying in Turkey generally show high values on average. Otherwise, the Perceived Behavioral Control (PBC) performs neither high nor low value. It indicates that the planned behavior factors as documented by Ajzen (1991) in his theory of planned behavior relatively compatible to explain the tendency of intention. Furthermore, the common perception of international students in Turkey relating to Entrepreneurial Intention (EI) is noted with a high mean score on average, in which the support of developing intention is apparently considered to be correlated to the planned behavior factors as delivered by Ajzen, (1991).

Additionally, retrieving to the results of structural analysis, we report that hypothesis one, two, four and six are statistically supported, while on the other hand hypothesis three and five are partially supported. Given the path analysis output, we contend that our result drawn quite hold with the previous study, where Personal Attitude (PA) and Perceived Behavioral Control (PBC) contribute more to Entrepreneurial Intention (EI) than Subjective Norm (SN).

\section{Appendix}

Operationalization of TPB model as adopted from the study of do Paço et al. (2011)

Table 10 Operationalisation of Personal Attitude (PA)

\begin{tabular}{|c|c|c|c|c|c|c|}
\hline \multirow[t]{2}{*}{ No } & \multirow[t]{2}{*}{ Item of questions } & \multicolumn{5}{|l|}{ Score } \\
\hline & & $\begin{array}{l}1 \\
\text { Strongly } \\
\text { disagree) }\end{array}$ & $\begin{array}{l}2 \\
\text { Disagree }\end{array}$ & $\begin{array}{l}3 \\
\text { Neither agree } \\
\text { nor disagree }\end{array}$ & $\begin{array}{l}4 \\
\text { Agree }\end{array}$ & $\begin{array}{l}5 \\
\text { Strongly } \\
\text { agree }\end{array}$ \\
\hline pa1 & $\begin{array}{l}\text { Being an entrepreneur implies more advantages } \\
\text { than disadvantages to me }\end{array}$ & & & & & \\
\hline pa2 & A career as entrepreneur is attractive for me & & & & & \\
\hline pa3 & $\begin{array}{l}\text { If I had the opportunity and resources, I'd like } \\
\text { to start a firm }\end{array}$ & & & & & \\
\hline pa4 & $\begin{array}{l}\text { Being an entrepreneur would entail great } \\
\text { satisfaction for me }\end{array}$ & & & & & \\
\hline pa5 & $\begin{array}{l}\text { Among various options, I would rather be } \\
\text { an entrepreneur }\end{array}$ & & & & & \\
\hline
\end{tabular}


Table 11 Operationalisation of Subjective Norm (SN)

\begin{tabular}{|c|c|c|c|c|c|c|}
\hline \multirow[t]{2}{*}{ No } & \multirow{2}{*}{$\begin{array}{l}\text { Item of } \\
\text { questions }\end{array}$} & \multicolumn{5}{|l|}{ Score } \\
\hline & & $\begin{array}{l}1 \\
\text { Strongly } \\
\text { disagree) }\end{array}$ & $\begin{array}{l}2 \\
\text { Disagree }\end{array}$ & $\begin{array}{l}3 \\
\text { Neither agree } \\
\text { nor disagree }\end{array}$ & $\begin{array}{l}4 \\
\text { Agree }\end{array}$ & $\begin{array}{l}5 \\
\text { Strongly } \\
\text { agree }\end{array}$ \\
\hline sn1 & Your close family & & & & & \\
\hline $\operatorname{sn} 2$ & Your friends & & & & & \\
\hline $\operatorname{sn} 3$ & Your colleagues & & & & & \\
\hline
\end{tabular}

When you decided to create a firm, would people in your close environment approve of that decision? Please Indicate from 1 (total disapproval) to 5 (total approval)

Table 12 Operationalisation of Perceived Behavioural Control (PBC)

\begin{tabular}{|c|c|c|c|c|c|c|}
\hline \multirow[t]{2}{*}{ No } & \multirow[t]{2}{*}{ Item of questions } & \multicolumn{5}{|l|}{ Score } \\
\hline & & $\begin{array}{l}1 \\
\text { Strongly } \\
\text { disagree) }\end{array}$ & $\begin{array}{l}2 \\
\text { Disagree }\end{array}$ & $\begin{array}{l}3 \\
\text { Neither agree } \\
\text { nor disagree }\end{array}$ & $\begin{array}{l}4 \\
\text { Agree }\end{array}$ & $\begin{array}{l}5 \\
\text { Strongly } \\
\text { agree }\end{array}$ \\
\hline $\mathrm{pbc1}$ & $\begin{array}{l}\text { To start a firm and keep it working would } \\
\text { be easy for me }\end{array}$ & & & & & \\
\hline $\mathrm{pbc2}$ & I am prepared to start a viable firm & & & & & \\
\hline $\mathrm{pbc3}$ & $\begin{array}{l}\text { I can control the creation process of a new } \\
\text { firm }\end{array}$ & & & & & \\
\hline $\mathrm{pbc4}$ & $\begin{array}{l}\text { I know the necessary practical details to } \\
\text { start a firm }\end{array}$ & & & & & \\
\hline $\mathrm{pbc5}$ & $\begin{array}{l}\text { I know how to develop an entrepreneurial } \\
\text { project f. If I tried to start a firm, I would have } \\
\text { a high probability of succeeding }\end{array}$ & & & & & \\
\hline
\end{tabular}

To what extent do you agree with the following statements regarding your entrepreneurial capacity? Please value them from 1 (total disagreement) to 5 (total agreement)

Table 13 Operationalisation of Entrepreneurial Intention (EI)

\begin{tabular}{|c|c|c|c|c|c|c|}
\hline \multirow[t]{2}{*}{ No } & \multirow[t]{2}{*}{ Item of questions } & \multicolumn{5}{|l|}{ Score } \\
\hline & & $\begin{array}{l}1 \\
\text { Strongly } \\
\text { disagree) }\end{array}$ & $\begin{array}{l}2 \\
\text { Disagree }\end{array}$ & $\begin{array}{l}3 \\
\text { Neither agree } \\
\text { nor disagree }\end{array}$ & $\begin{array}{l}4 \\
\text { Agree }\end{array}$ & $\begin{array}{l}5 \\
\text { Strongly } \\
\text { agree }\end{array}$ \\
\hline ei1 & I am ready to do anything to be an entrepreneur & & & & & \\
\hline ei2 & My professional goal is to become an entrepreneur & & & & & \\
\hline ei3 & I will make every effort to start and run my firm & & & & & \\
\hline ei4 & I am determined to create a firm in the future & & & & & \\
\hline ei5 & I have very seriously thought of starting a firm & & & & & \\
\hline ei6 & I have the firm intention to start a firm someday & & & & & \\
\hline
\end{tabular}

Please Indicate your level of agreement with the following statements starts from 1 (total disagreement) to 5 (total agreement)

\section{Abbreviations}

El: entrepreneurial intention; PA: personal attitude; PBC: perceived behavioral control; SN: subjective norm; TPB: theory of planned behavior

\section{Acknowledgements}

We are grateful to Nezameddin Faghih (Editor-in-Chief of JGER), two anonymous peer reviewers for their constructive comments, Matin Mohaghegh, Muhammad Hafidz Naeem (University of Padua), Willy Abdillah (University of Bengkulu), Mohammad Morad (Shahjalal University of Technology and Science), Mahir Djibril, Rajab led Muyinggo, 
Nega Muhabbaw Kassie, and Khaalid Cabdiraxmaan (Marmara Üniversitesi). The comment(s) and suggestion(s) from the participants of 2nd Uluslararası Öğrenciler Sosyal Bilimler Kongresi (International Students Social Sciences Congress) at the Necmettin Erbakan Üniversitesi, Konya - Turkey, are also acknowledged.

\section{Funding}

Not applicable.

\section{Availability of data and materials}

Our data is provided in the confidential form. In the survey, we informed the respondents that the data will not be shared or disseminated to the third-party.

\section{Authors' contributions}

Eighty percent of the total manuscript was written by Berto Usman (BU) and $20 \%$ remaining provided by both authors Berto Usman \& Yennita (BU \& Y). Literature part, methodology, data collection and data analysis were conducted by $\mathrm{BU}$, while other aspects were the combined efforts between the $\mathrm{BU}$ and $\mathrm{Y}$. $\mathrm{BU}$ and $\mathrm{Y}$ read and approved the final manuscript and agreed to submit it to the Journal of Global Entrepreneurship Research.

\section{Ethics approval and consent to participate}

Not applicable.

\section{Consent for publication}

Not applicable.

\section{Competing interests}

The authors declare that they have no competing interest.

\section{Publisher's Note}

Springer Nature remains neutral with regard to jurisdictional claims in published maps and institutional affiliations.

\section{Author details}

'Department of Management, Faculty of Economics and Business, University of Bengkulu, Jalan. WR Supratman, Kandang Limun, Bengkulu 38121, Indonesia. 'Faculty of Teacher Training and Education, University of Bengkulu, Jalan. WR Supratman, Kandang Limun, Bengkulu 38121, Indonesia.

Received: 18 March 2018 Accepted: 5 December 2018

Published online: 08 January 2019

\section{References}

Ajzen, I. (1985). From intentions to actions: A theory of planned behavior. In Action control (pp. 11-39). https://doi.org/10. 1007/978-3-642-69746-3_2

Ajzen, I. (1991). The theory of planned behavior. Organizational Behavior and Human Decision Processes, 50(2), 179-211. https://doi.org/10.1016/0749-5978(91)90020-T.

Boukamcha, F. (2014). Impact of training on entrepreneurial intention: An interactive cognitive perspective. European Business Review, 27(6), 593-616.

Buttar, H. M. (2015). Formation of entrepreneurial career intentions: The role of sociocognitive factors. Journal of Employment Counseling, 52(1), 2-17. https://doi.org/10.1002/j.2161-1920.2015.00052.x.

Carr, J. C., \& Sequeira, J. M. (2007). Prior family business exposure as intergenerational influence and entrepreneurial intent: A theory of planned behavior approach. Journal of Business Research, 60(10), 1090-1098. https://doi.org/10.1016/j.jbusres.2006.12.016.

Chin, W. (1998). The partial least squares approach to structural equation modeling. Modern Methods for Business Research 295(2), 295-336. https://doi.org/10.1016/j.aap.2008.12.010.

do Paço, A. M. F., Ferreira, J. M., Raposo, M., Rodrigues, R. G., \& Dinis, A. (2011). Behaviours and entrepreneurial intention: Empirical findings about secondary students. Journal of International Entrepreneurship, 9(1), 20-38. https://doi.org/10.1007/ s10843-010-0071-9.

Engel, J. F., Blackwell, R. D., \& Miniard, P. W. (1995). Consumer behavior (Vol. 12). Chicago: Dry den. https://doi.org/10.1016/j. intmar.2010.02.005.

Florin, J., Karri, R., \& Rossiter, N. (2007). Fostering entrepreneurial drive in business education: An attitudinal approach. Journal of Management Education, 31(1), 17-42. https://doi.org/10.1177/1052562905282023.

Gefen, D. (2000). Structural equation modeling and regression : Guidelines for research practice structural equation modeling and regression: Guidelines for research practice. Structural Equation Modeling, 4(August), 7 10.1.1.25.781.

Hair, J. F., Black, W. C., Babin, B. J., \& Anderson, R. E. (2010). Multivariate data analysis. Vectors. https://doi.org/10.1016/j.jpharm. 2011.02.019.

Haugh, H. (2005). A research agenda for social entrepreneurship. Social Enterprise Journal, 1(1), 1-12. https://doi.org/10.1108/ 17508610580000703.

Henseler, J., \& Chin, W. (2010). A comparison of approaches for the analysis of interaction effects between latent variables using partial least squares path modeling. Structural Equation Modeling: A Multidisciplinary Journal, 17(1), 82-109. https:// doi.org/10.1080/10705510903439003.

Hisrich, R. D., Bucar, B., \& Oztark, S. (2003). A cross-cultural comparison of business ethics: Cases of Russia, Slovenia, Turkey, and United States. Cross Cultural Management: An International Journal, 10(1), 3-28. https:/doi.org/10.1108/13527600310797504. 
Kamaludin, K., \& Usman, B. (2016). The dynamics and decision making process of conducting post-graduate study in school of management. Res J Bus Manag, 3(1), 107-107. https://doi.org/10.17261/Pressacademia.2016116567.

Kautonen, T., van Gelderen, M., \& Fink, M. (2015). Robustness of the theory of planned behavior in predicting entrepreneurial intentions and actions. Entrepreneurship: Theory and Practice, 39(3), 655-674. https://doi.org/10.1111/etap.12056.

Krueger, N. F., Reilly, M. D., \& Carsrud, A. L. (2000). Competing models of entrepreneurial intentions. Journal of Business Venturing, 15(5-6), 411-432. https://doi.org/10.1016/S0883-9026(98)00033-0.

Lortie, J., \& Castogiovanni, G. (2015). The theory of planned behavior in entrepreneurship research: What we know and future directions. International Entrepreneurship and Management Journal, 11(4), 935-957. https://doi.org/10. 1007/s11365-015-0358-3.

Mertens, W., Pugliese, A., \& Recker, J. (2016). Quantitative data analysis: A companion for accounting and information systems research. Quantitative data analysis: A companion for accounting and information systems research. Switzerland: Springer International Pubishing Switzerland. https://doi.org/10.1007/978-3-319-42700-3.

Miller, B. K., Bell, J. D., Palmer, M., \& Gonzalez, A. (2009). Predictors of entrepreneurial intentions: A quasi-experiment comparing students enrolled in introductory management and entrepreneurship classes. Journal of Business and Entrepreneurship, 21(2), 39-62. https://doi.org/10.1017/CBO9781107415324.004.

Molaei, R., Zali, M. R., Mobaraki, M. H., \& Farsi, J. Y. (2015). The impact of entrepreneurial ideas and cognitive style on students entrepreneurial intention. Journal of Enterpreneurship in Emerging Economies, 7(2), 148-167. https://doi.org/10.1 108/JEEE10-2015-0058

Mueller, J., Zapkau, F. B., \& Schwens, C. (2014a). Impact of prior entrepreneurial exposure on entrepreneurial intention - crosscultural evidence. Journal of Enterprising Culture, 22(3), 251. https://doi.org/10.1142/S0218495814500113.

Noorkatina, M., Lim, H.E., \& Soon, N. Y. J. J. (2015). Estimating the effect of entrepreneur education on graduates' intention to be entrepreneurs. Education and Training, 57(8/9), 836-848.

Palmer, J., Griswold, M., Eidson, V., \& Wiewel, P. (2015). Entrepreneurial intentions of male and female university students. Int $J$ Business Public Admin, 12(1), 152-167.

Patache, L., \& Mitran, P. C. (2014). Entrepreneurial intention of students and unemployed persons in Romania: A case study on the south-east region and the south-west - Oltenia region. Economics, Management and Financial Markets, 9(4), 282-295.

Rushing, F. (1990). Entrepreneurship and education. In C. Kent (Ed.), Entrepreneurship education current developments, future directions. New York: Quoru Books. https://doi.org/10.3200/JOEB.84.3.151-159.

Ryan, S. T. J. (2016). Predicting entrepreneurial intentions from work values: Implications for stimulating entrepreneurship in UAE national youth. Management Decision, 54(3), 1-27.

Sarstedt, M., Henseler, J., \& Ringle, C. M. (2011). Multigroup analysis in partial least squares (PLS) path modeling: Alternative methods and empirical results. Advances in International Marketing, 22(November 2016), 195-218. https://doi.org/10.1108/ S1474-7979.

Souitaris, V., Zerbinati, S., \& Al-Laham, A. (2007). Do entrepreneurship programmes raise entrepreneurial intention of science and engineering students? The effect of learning, inspiration and resources. Journal of Business Venturing, 22(4), 566-591. https://doi.org/10.1016/j.jbusvent.2006.05.002.

Sušanj, Z., Jakopec, A., \& Miljković Krečar, I. (2015). Verifying the model of predicting entrepreneurial intention among students of business and non-business orientation. Management, 20(2), 49-69.

Usman, B. (2016). A glimpse of entrepreneurial intention : empirical finding of international students' perspectives in Turkey. In 2th International Students Social Sciences (pp. 1-11). Konya.

Wilson, F., Kickul, J., Marlino, D., Barbosa, S. D., \& Griffiths, M. D. (2009). An analysis of the role of gender and self-efficacy in developing female entrepreneurial interest and behavior. Journal of Developmental Entrepreneurship, 14(02), 105-119. https://doi.org/10.1142/S1084946709001247.

Zhang, P., Wang, D. D., \& Owen, C. L. (2015). A study of entrepreneurial intention of university students. Entrepreneurship Research Journal, 5(1), 61-82. https://doi.org/10.1515/erj-2014-0004.

\section{Submit your manuscript to a SpringerOpen ${ }^{\circ}$ journal and benefit from:}

- Convenient online submission

- Rigorous peer review

- Open access: articles freely available online

- High visibility within the field

- Retaining the copyright to your article

Submit your next manuscript at $\boldsymbol{s p r i n g e r o p e n . c o m ~}$ 